\title{
Amateur/Avocational Contributions to Paleontology - The Big Picture
}

\author{
Linda McCall \\ North Carolina Fossil Club \\ Research Fellow - University of Texas - Austin
}




\section{AA Paleontological Types}

Individual Collector

Commercial Operation

Fossil Club/Society Member 


\section{Individual Collector}

(since the dawn of humanity)

- Not a member of a club, collect for research, fun or profit

- MANY GOOD FOR SCIENCE (research driven)

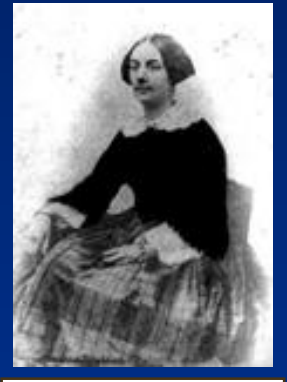

Elizabeth

Philpot

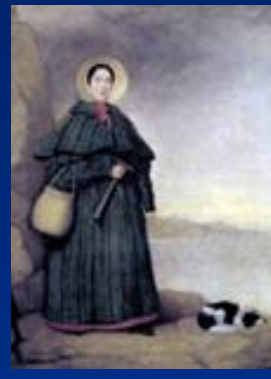

Mary Anning

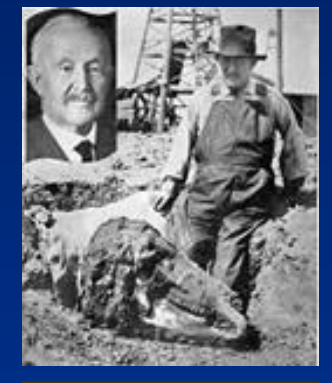

Charles Sternberg

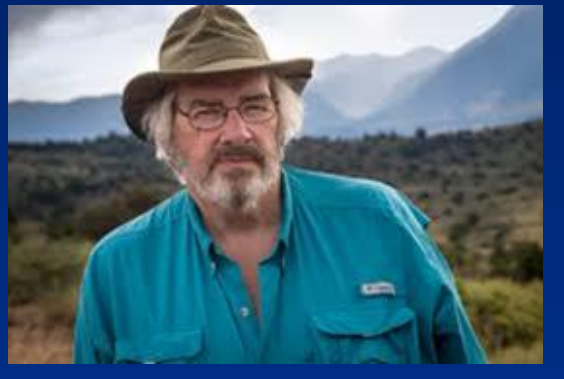

Jack Horner

- SOME NOT SO GOOD FOR SCIENCE

- Internet/eBay - explosion of folks out to find fossils just to sell - no interest in science, give the rest of us a bad name 


\section{Commercial Operations}

Dealers

- Dealers

- Collect, prep and sell (research component)

- Black Hills Institute of Geological Research, Inc. (Peter Larson)

- Geological Enterprises, Inc. (Donna Russell)

- Black Cat Mountain Trilobites (Bob Carroll)

- Trilobites of America (Dan Cooper) (Dry Dredgers)

- Cold Creek Fossils (Danny Harlow) (PoSA)

- Just buy and sell (little or no research component)

- Many more since internet/eBay....

With fossils becoming "hot" to own, explosion of folks with no interest in the science - in to make money 


\section{Commercial Operations "Pay to Dig"/Ecotourism ('80's -)}

- "Pay to Dig"/Ecotourism (research component)

- U-Dig Fossils - Utah

- Paleo Adventures - Walter Stein

- Frank Garcia

- Mark Renz

- Mid-Atlantic Fossil and Nature Adventures (Cathy Young/“Buck” Ward)

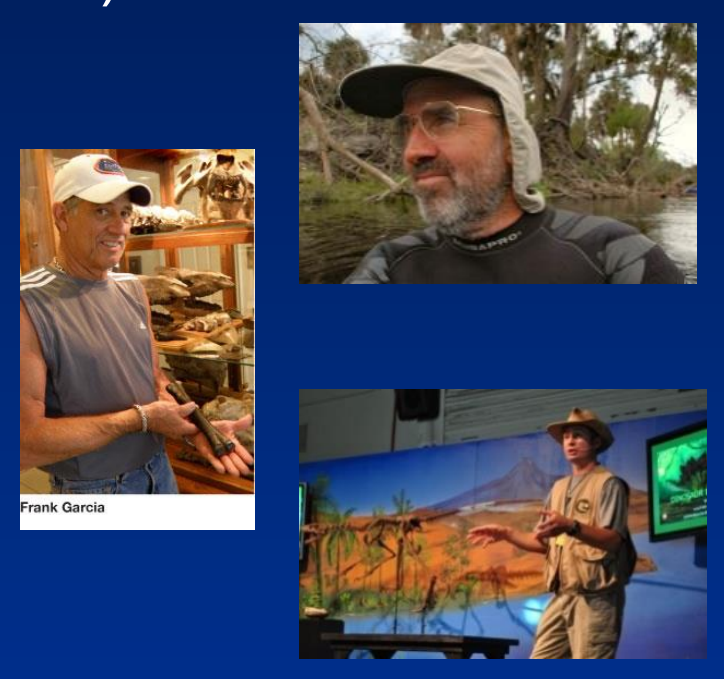

- Positive impact in both education and outreach

- Engage the public in hands-on paleontological experiences in the field 


\section{Fossil Clubs/Societies (60's - 80's)}

- Most clubs/societies formed 60's to 80's

- No different than shell clubs, mineral clubs, etc.

- Not in it for profit

- Social aspect, fun, education and research

- Interested in paleontology and the science

- Enjoy collecting in the field (20\%)

- Knowledgeable about their area of interest

- Seek further education

- Frequently partner with museums and universities

- Heavy into community outreach

- Group setting provides modeling and reinforcement for ethical behavior

- Clear positive educational and scientific impact 


\section{Fossil Clubs/Societies}

\section{2,000 members nationwide}

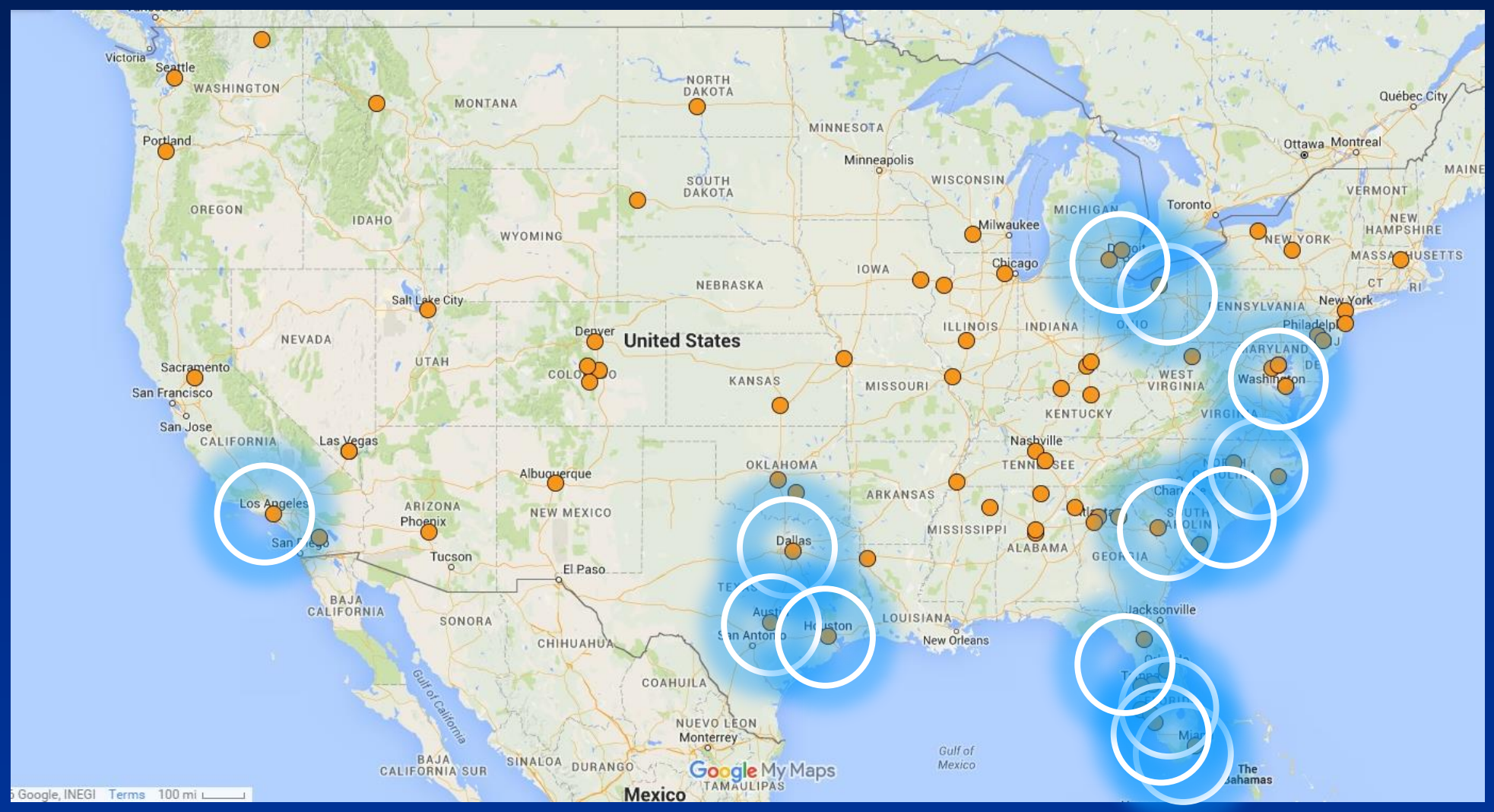

myFOSSIL

60 clubs/societies 


\section{Club Structure Basics}

- 501 (c) (3)

- By-laws / Mission Statement

- Ethics Policy

- Liability Insurance

- Elected Officers / Board of Directors

- Professional Advisors

- Website / Social Media

- Grants / Scholarships / Donations

- Affiliates 


\section{Today's Fossil Clubs}

- Collect in the field - ethically

- Curate/Catalogue/Collections/Displays

- Research

- Publish - articles/papers/books

- Publish - peer-reviewed

- Public outreach

- Grants/scholarships/donations

- Basically the things professionals do
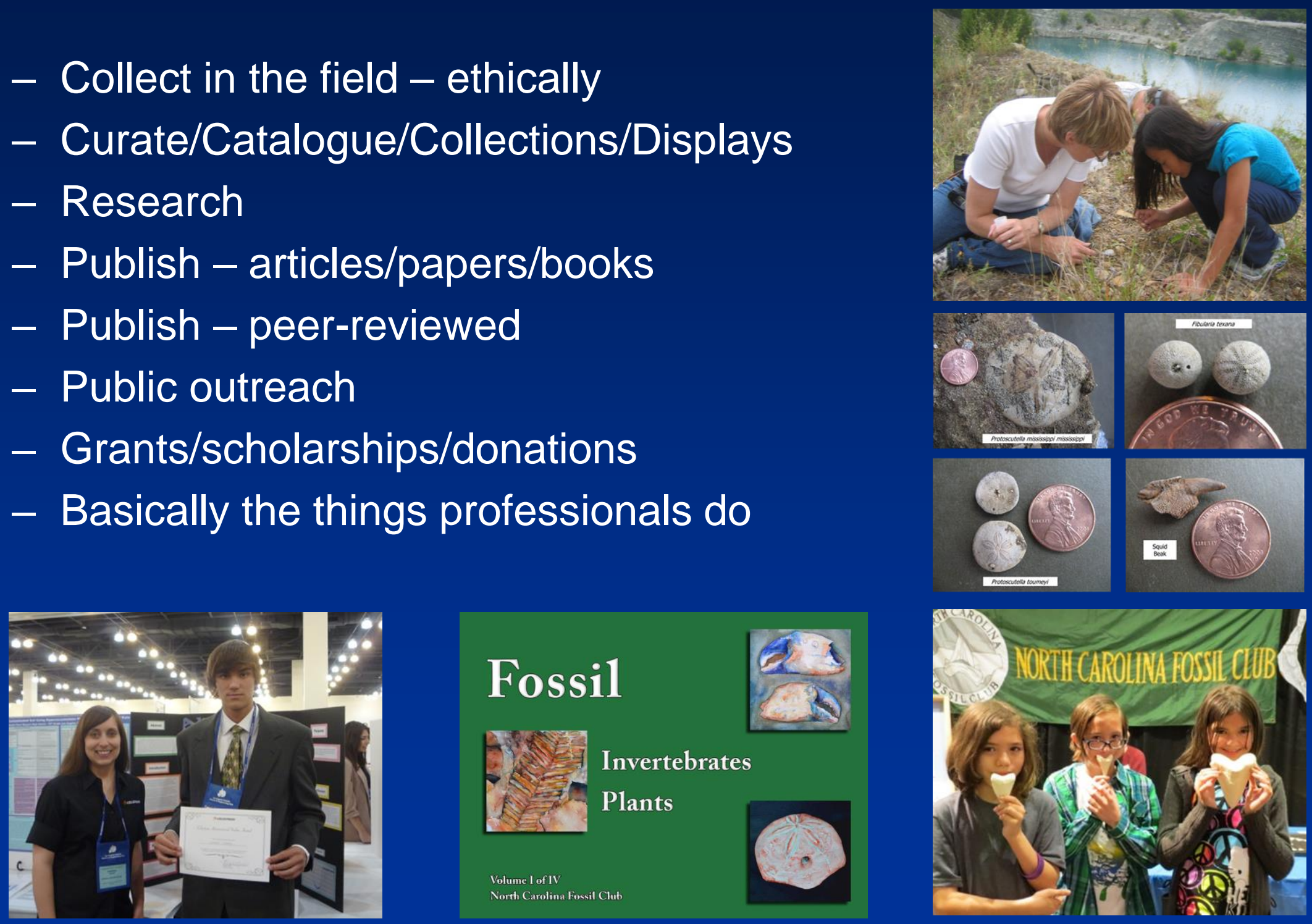


\section{Today's Fossil Clubs}

- Volunteer time

- Communicate good sites/finds

- Donate exceptional specimens

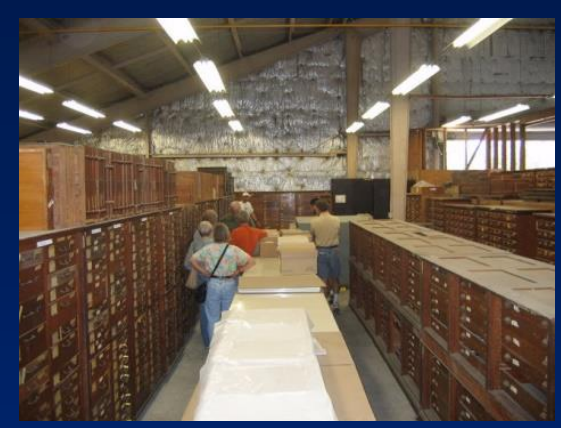

- Eclectic group of individuals

- Passion for Paleontology, from all walks of life

- Wide range of knowledge

- Wide range of talents - outreach, organization, trips, publishing, photography, web savvy, etc..

- Creating effective and impactful organizations

- Share in common a love for fossils and thirst for knowledge

- Many not professional paleontologists but just as passionate - maybe more so
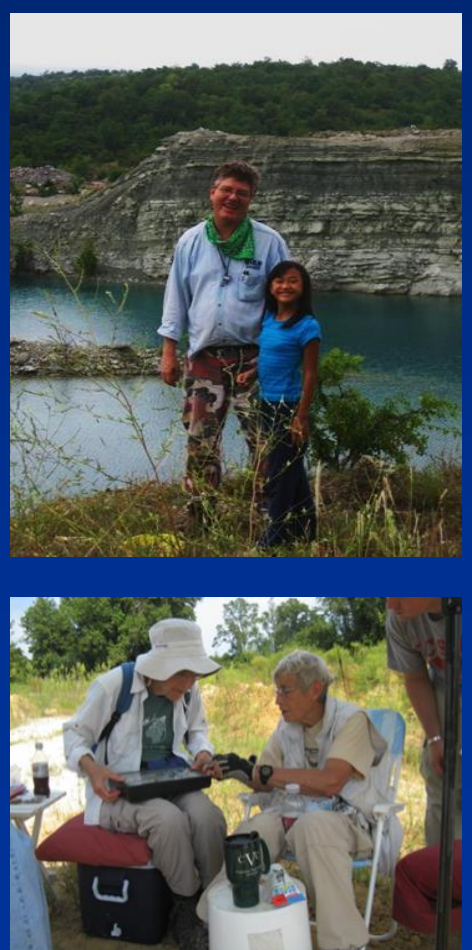


\section{Meetings/Speakers}

- Meetings / guest lecturer forum

- Professional Paleontologists

- Grad students

- Avocational Paleontologists

- Fellow club members

- Business meeting / show-n-tell / door prizes

- Auction / Christmas Party / Picnic

- Raise money

- Speakers

- Food, fun and fossils
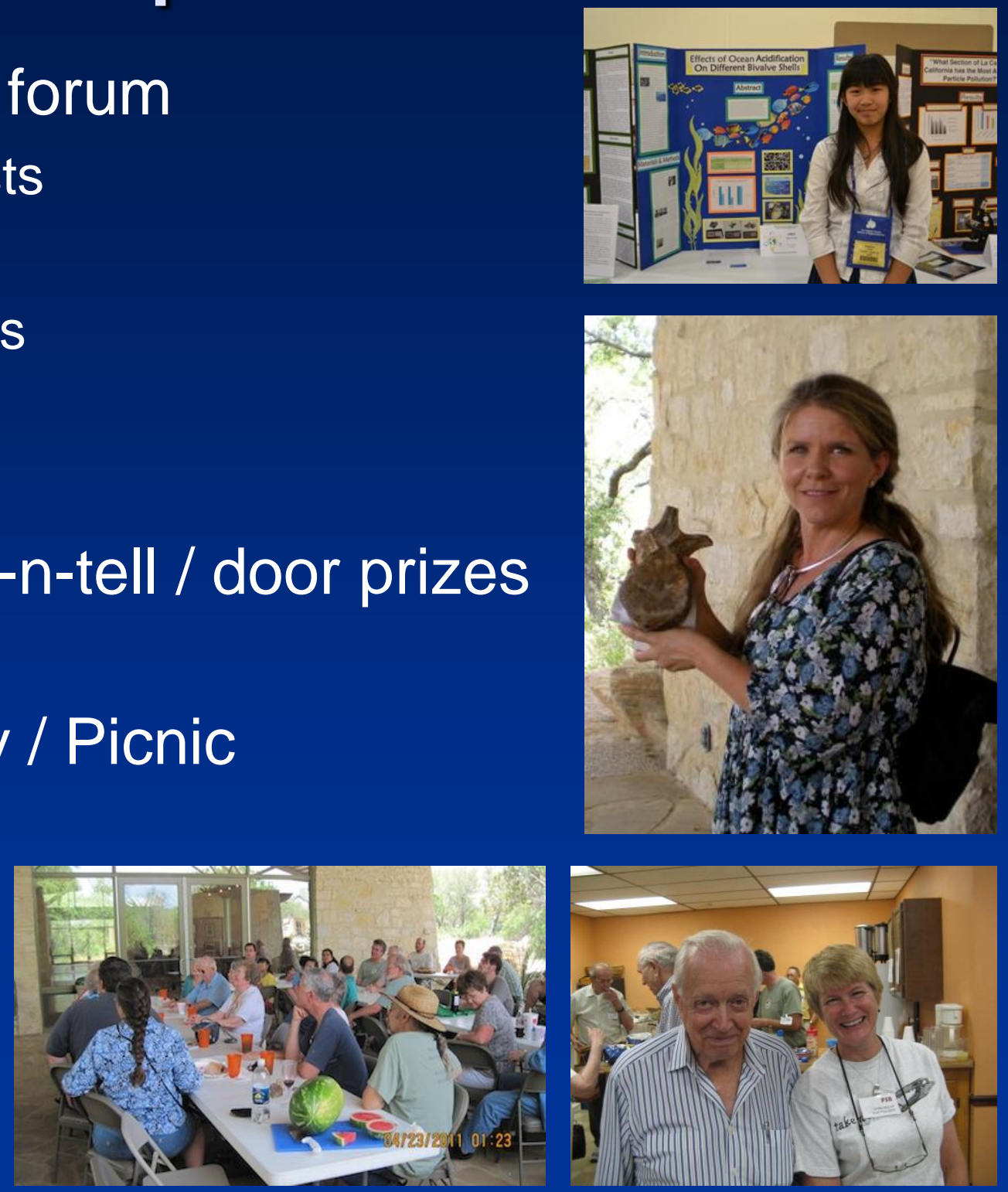


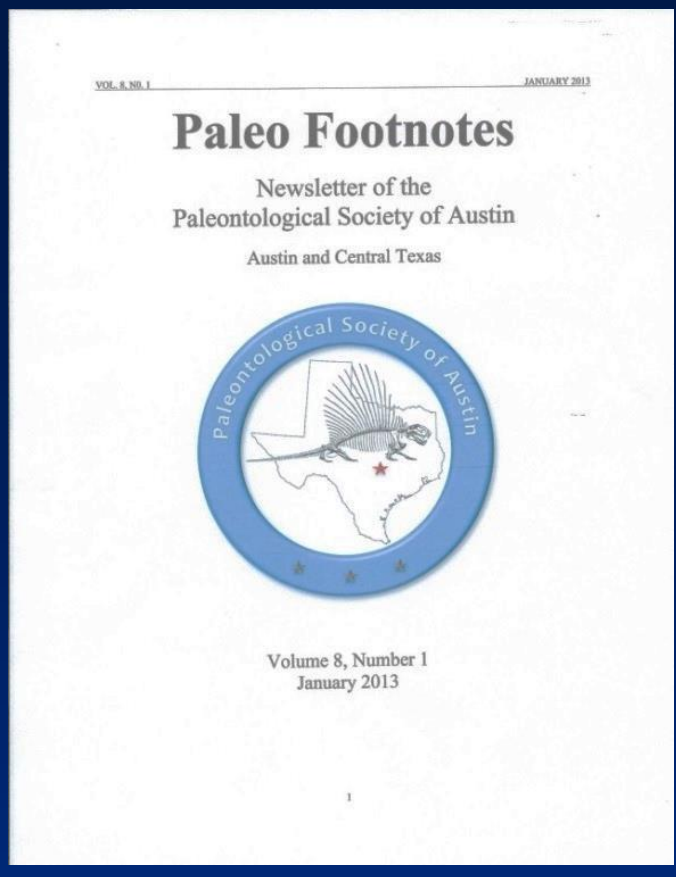

\section{Newsletters}

- Presidents note

- Speaker topic \& bio

- Fossil articles

- Field Trip reports

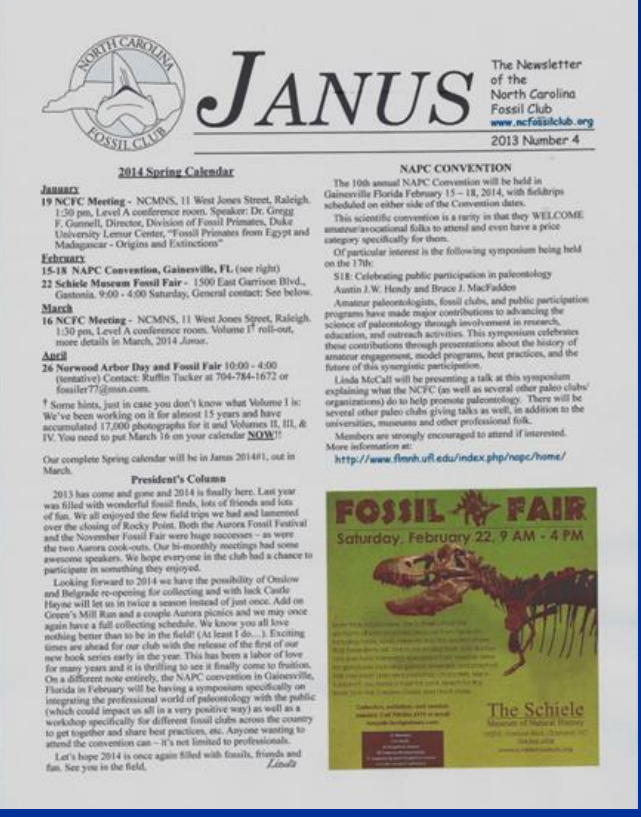

- Future Trip notices

- Calendar of Events

- Club officers contact

- Membership info
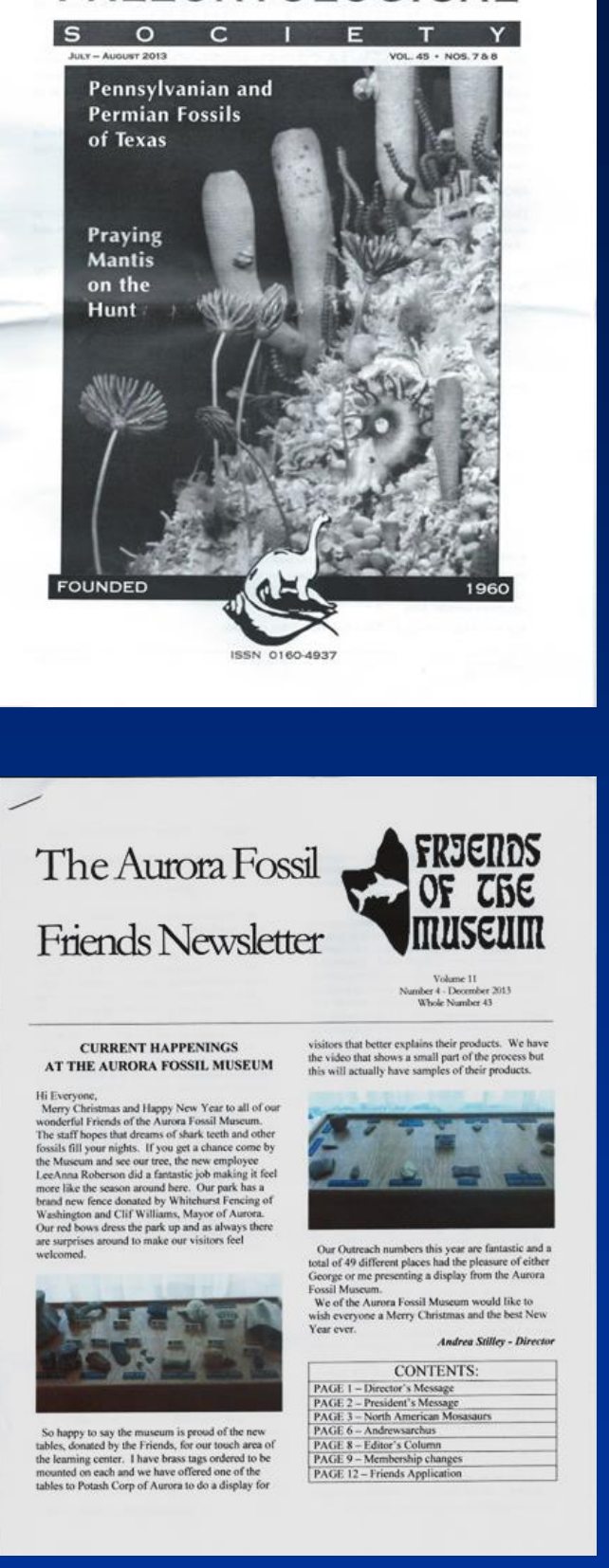
First point of contact for the general public

- Many clubs have outstanding websites, virtual portals to connect with and educate the general public as well as a forum for club members to obtain and disseminate information as well as fossil ID sections.

- ncfossilclub.org

- dallaspaleo.org

- austinpaleo.org

- southwestfloridafossilclub.com

\section{Social Media}

- afmfriends,org

- floridapaleosociety.com

- socalpaleosociety.wordpress.com

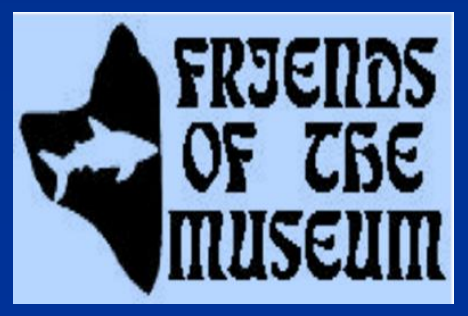




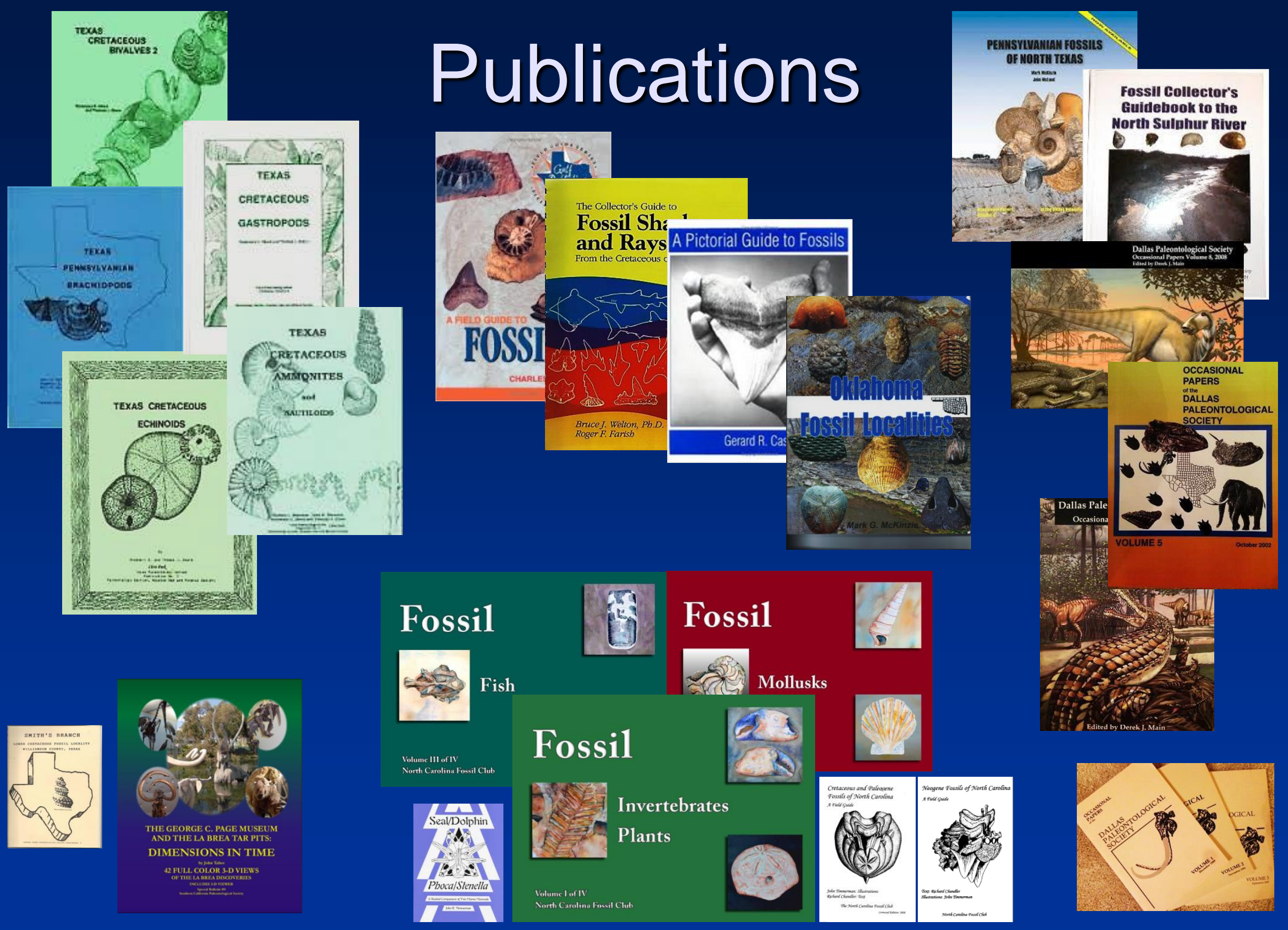




\section{Public Outreach \& Results (Schools / Museums / Libraries / Fairs)}

- 185 outreach events 15 clubs (740 / 60)

- 185 events impacted 70,000 (280,000 / 60)

- We are the face of Paleontology to the general public in our communities

- Hundreds of THOUSANDS of fossils given away annually. At $\sim 500$ lbs per club X 15 clubs $=3$ TONS of fossils

- 60 clubs = 12 TONS of fossils annually
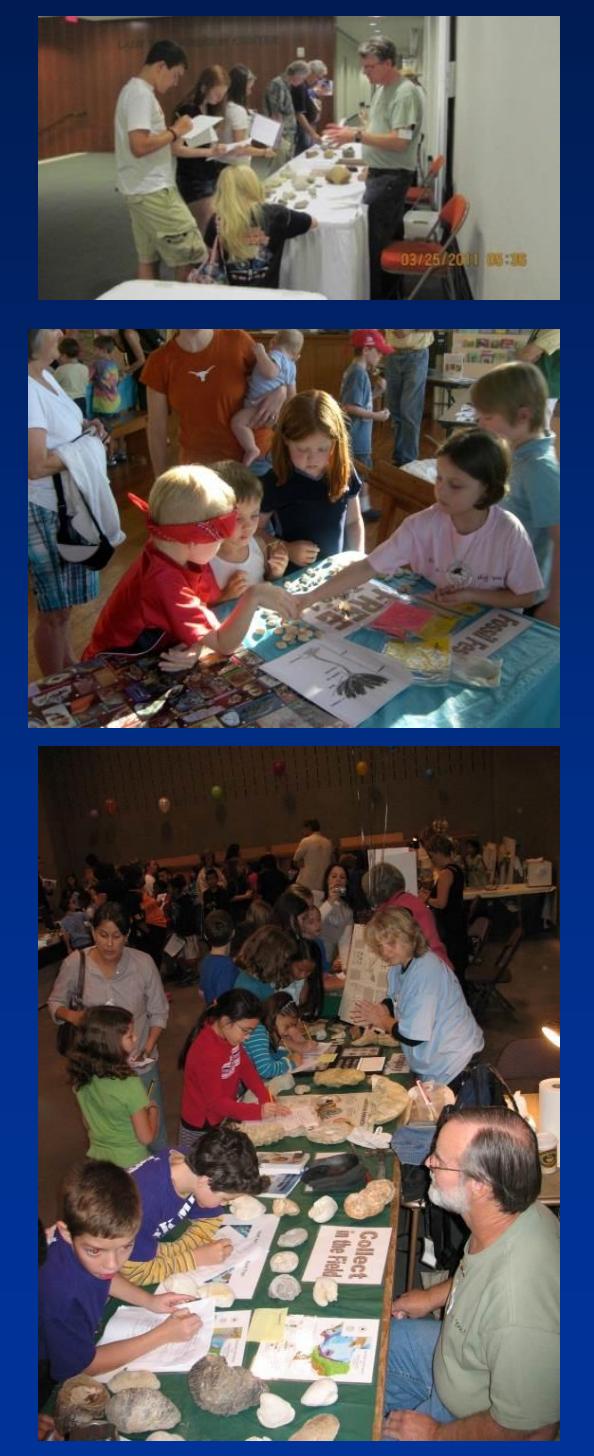


\section{Outreach}
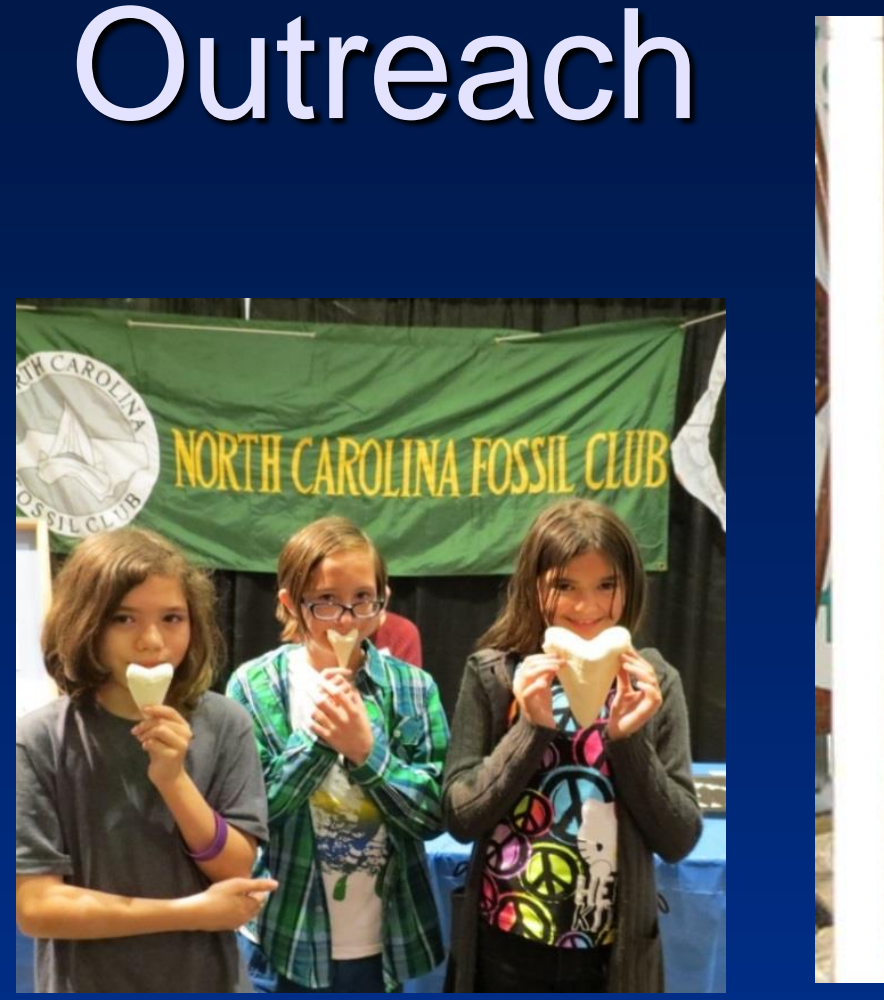

Rocks!
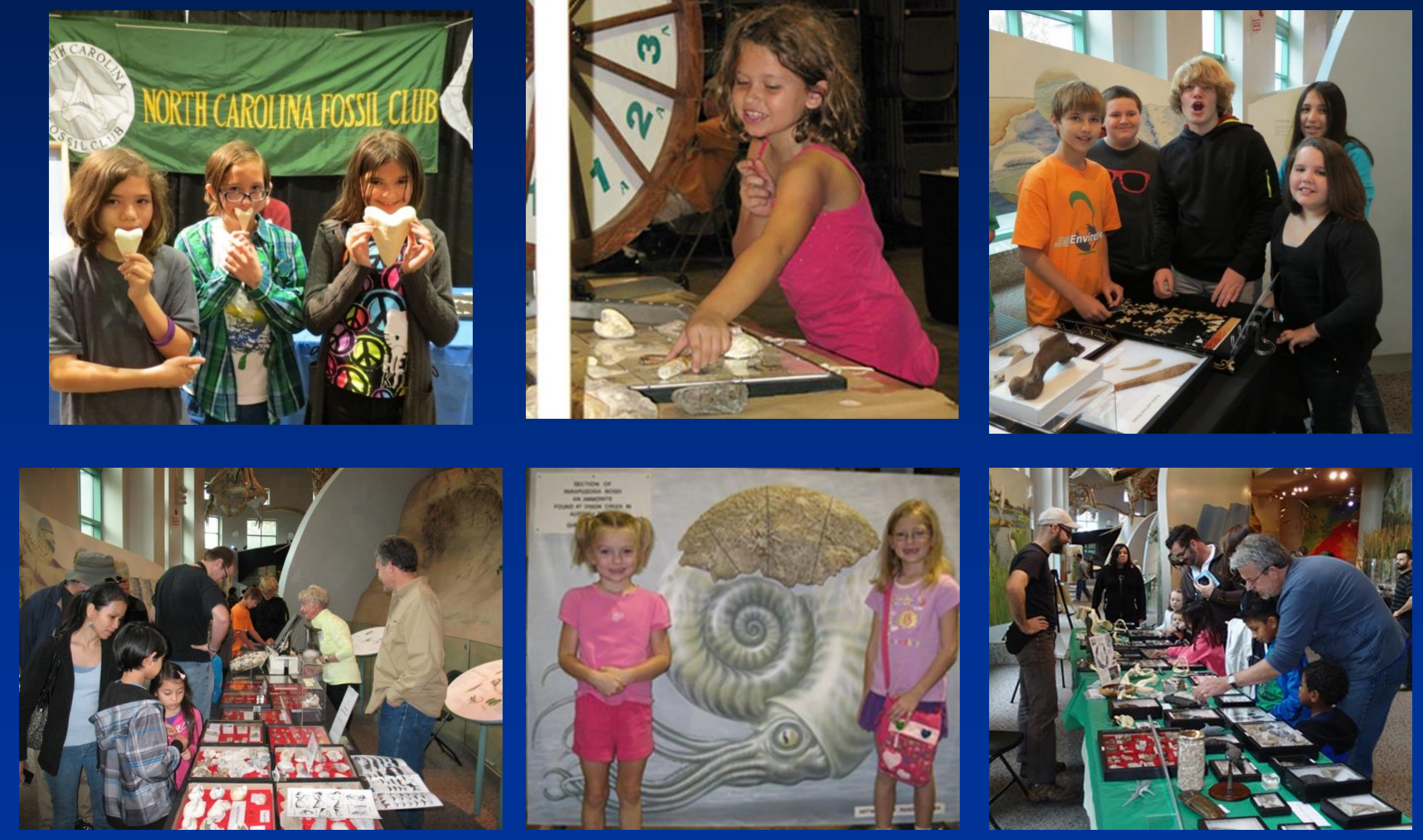


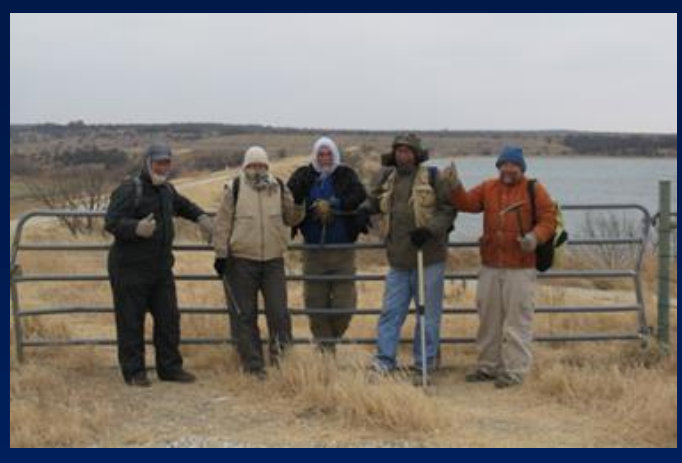

\section{Field Trips}

Fossils, non-renewable resource, but...

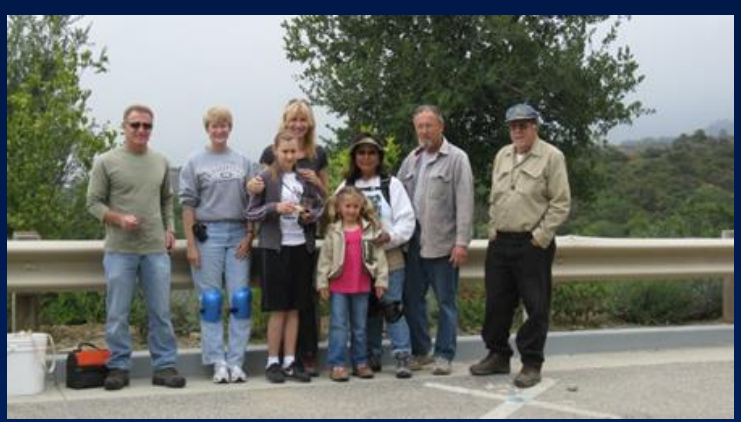

- Clubs were formed in part because folks loved to collect in the field And it leads to all the positive things we have just discussed.

- $~ 10$ trips per year $\times 60$ clubs $=600$ field trips $\times 20=12,000$ people

- Exposed fossils have a finite life span

- For every significant fossil you lose to a private collector you obtain hundreds more. The balance is clearly in favor of us being out there collecting.

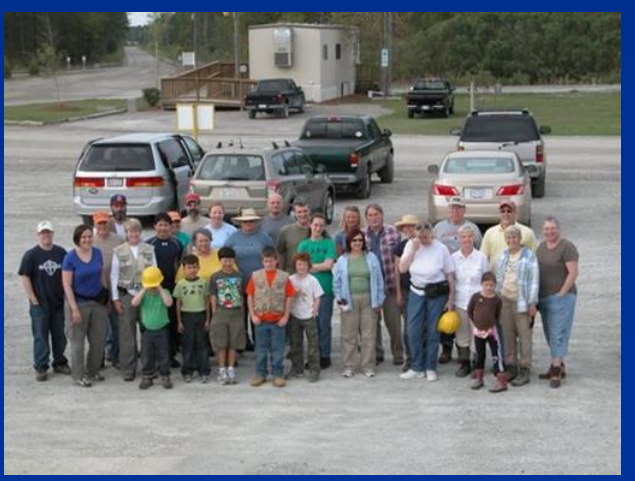

Remember

that 12 TONS

of fossils we

give away

annually??

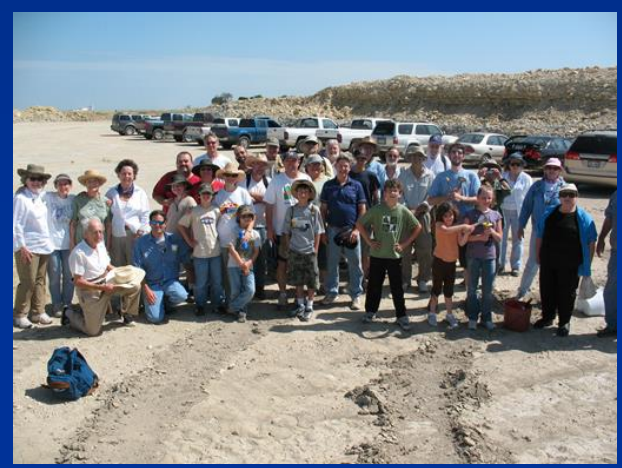




\section{Professional Interaction}

- 14 of 15 clubs/societies surveyed actively interact with processional organizations

- help out on projects

- donate thousands of man-hours annually

- Most have professionals as members or advisors

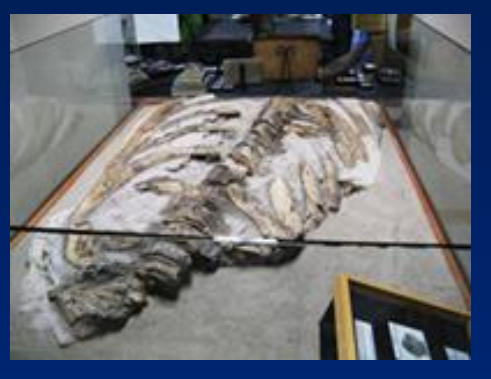

- Many professionals friendly to the AA community

- Dr. Dave Bohaska

- Dr. Bruce McFadden

- Dr. George Phillips

- Dr. Lyle Campbell

- Dr. David Campbell

- Dr. Roger Portell
- Dr. Ann Molineux

- Dr. James Sprinkle

- Dr. Ernie Lundelius

- Dr. Wann Langston

- Dr. Stephen Godfrey

- The Paleontological Society 


\section{My Story}

- Early love of Paleontology

- Began collecting fossils at age 6

- Moved to Texas at age 12 - fossils were everywhere!

- Individual collector until age 19

- Joined paleo section of the AGMS - eventually became PoSA

- Went to UT as a Geology Major 1975-1977

- Worked at VP lab under Dr. Wann Langston and Dr. Ernie Lundelius as a freshman

- Counselors told me, "you're a girl - best you can get is oil and gas and microbes".

- Dropped out, got married, took a day job, had kids 


\section{My Story}

- Continued pursuing paleontology as a club member

- Going on field trips

- Amassing collections

- Teaching myself, learning from fellow club members

- Co-authored first paper as a club project w/ Dr. Jim Sprinkle (club science advisor) and others in 1985

- Began publishing peer reviewed material at age 51

- Lead authored \& presented first paper w/ mentor Dr. Ann Molineux and Dr. Jim Sprinkle in 2008. Paper won $2^{\text {nd }}$ best paper at GCAGS conference - almost couldn't attend to give the presentation 


\section{My Story}

- Continued research and peer reviewed publishing

- Lead authored \& presented my $2^{\text {nd }}$ paper in 2010 (GCAGS)

- Both papers were reprinted in the South Texas Geological Society Bulletin as Cover Articles

- Lead authored my $3^{\text {rd }}$ paper in 2012 - and won $3^{\text {rd }}$ place for best presentation (GCAGS) (some push-back on my eligibility to receive the award)

- Presented my first solo abstract at NAPC in 2014

- Lead authored and presented my first GSA abstract in 2015 on 30 million old preserved fossil color

- Currently presenting this abstract 2016 (SEGSA)

- Continuing research on fossil color as well as preserved 2 million year old ligament 


\section{Peer-Reviewed}

- 51 AA individuals peer-reviewed out of 15 clubs surveyed

- Numerous Strimple Award winners

- 1985. W. H. White, Jr. (Dry Dredgers)

- 1992. Gerald R. Case (NCFC)

- 1993. Peter J. Harmatuk (NCFC)

- 1998. Peter LeGrand Smith (NCFC)

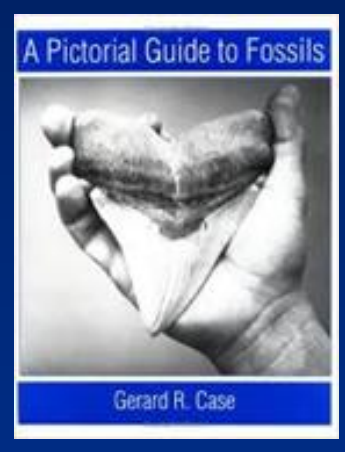

- 2001. Stephen Felton (Dry Dredgers)

- 2006. Christopher L. Garvie (PoSA)

- 2008. Tom Witherspoon (FUMMP)

- 2011. Michael and John Topor (FUMMP)

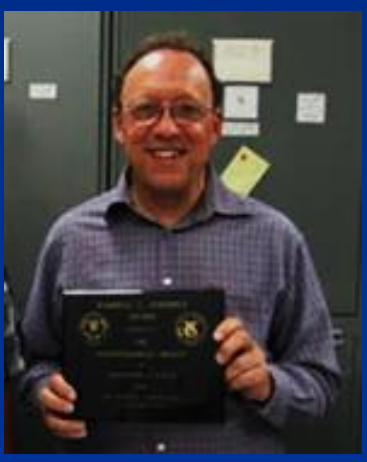




\section{Launchpad to Professionalism}

- Clubs/Societies serve as a conduit through which members are inspired to join the ranks of the professionals - not to mention those we inspire through our outreach.

- George Phillips: went back to school at age 45 - now Paleontology Curator at the Mississippi Museum of Natural Science

- Cindy Crane: former NCFC member, went back to school - now Director of the Aurora Fossil Museum 


\section{AA Accomplishments}

- Aurora Fossil Museum
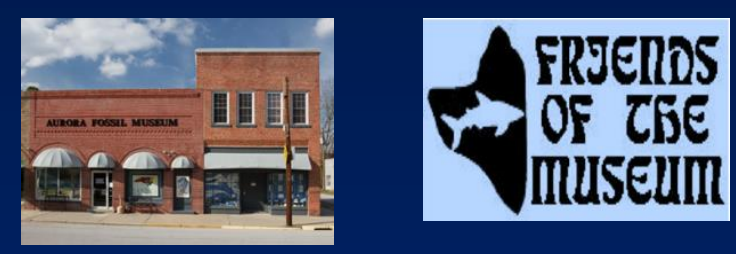

- 1976, AA conceived, supported and run for 40 years

- Fossil Forum

- Online venue for professionals and AAs to come together and share knowledge and finds

- Mineral Wells Fossil Park

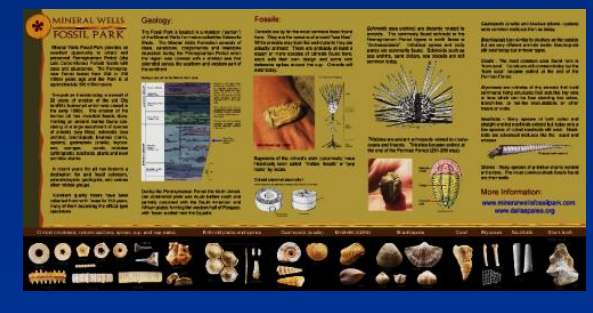

- Conceived by the Dallas Club with support from other TX organizations to save a fossiliferous land-fill pit from development and create a fossil park for the general public 


\section{We Pay Our Own Way}

- All our accomplishments are done on volunteer hours / no pay.

- We don't have employers or funding or grants to accomplish all the things we do.

- \$20.00 in annual dues + fundraisers covers meetings, newsletters, website upkeep and content, collecting trips, publishing, grant and scholarship award donations, etc.

- Additional collecting, researching, publishing, attending conventions, etc. is done on our own personal dime. 


\section{What AA Clubs have to offer}

MONEY: Grants/Donations/Scholarships

- 15 clubs donated over $\$ 16,000.00$ last year

- Average $\$ 1,225.00$ x 60 clubs

$\$ 73,500$ last year in donations to professionals
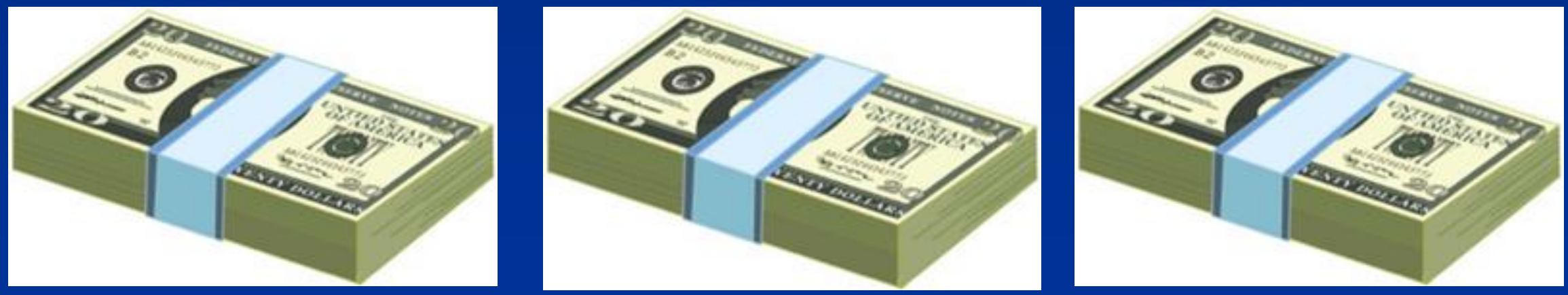


\section{What AA Clubs have to offer}

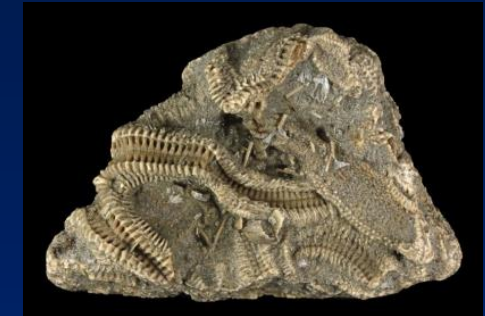

\section{FOSSIL \\ DONATIONS}

Can citizen scientists make a difference?

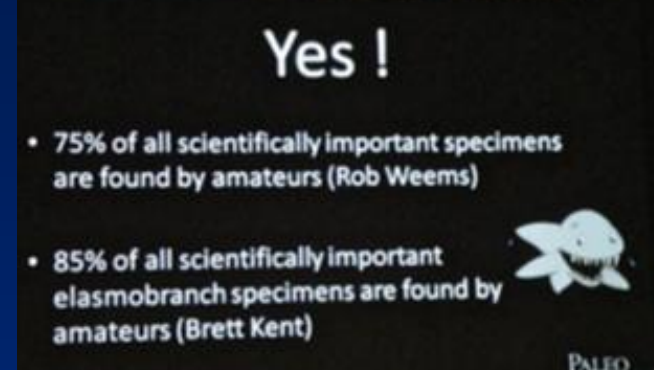

- Every club surveyed donated specimens

- How many? Thousands every year

- I've personally donated tens of thousands of specimens to UT

- $75 \%$ of scientifically relevant specimens were donated by amateurs. (Source: Paleo Quest) - I assume invertebrates

- Imagine your collections missing those specimens. Imagine all papers that wouldn't have been written and knowledge that wouldn't exist.
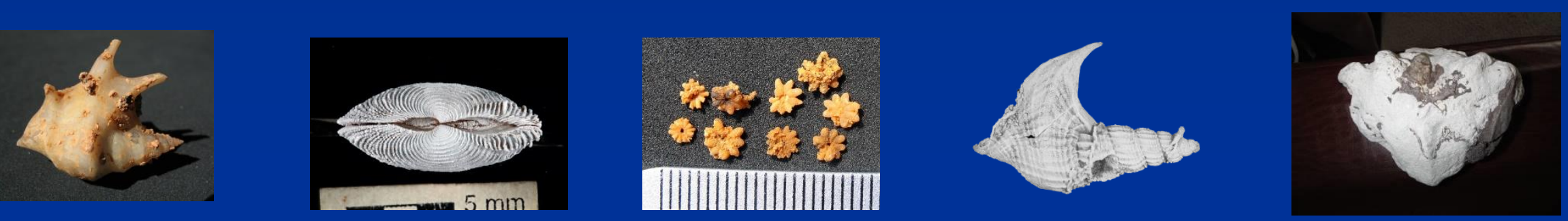


\section{What AA Clubs have to offer}

We are the face of Paleontology in our communities

(740 venues, 280,000 people, 12 TONS of fossils)

(plus everyone we reach through our websites and publications)
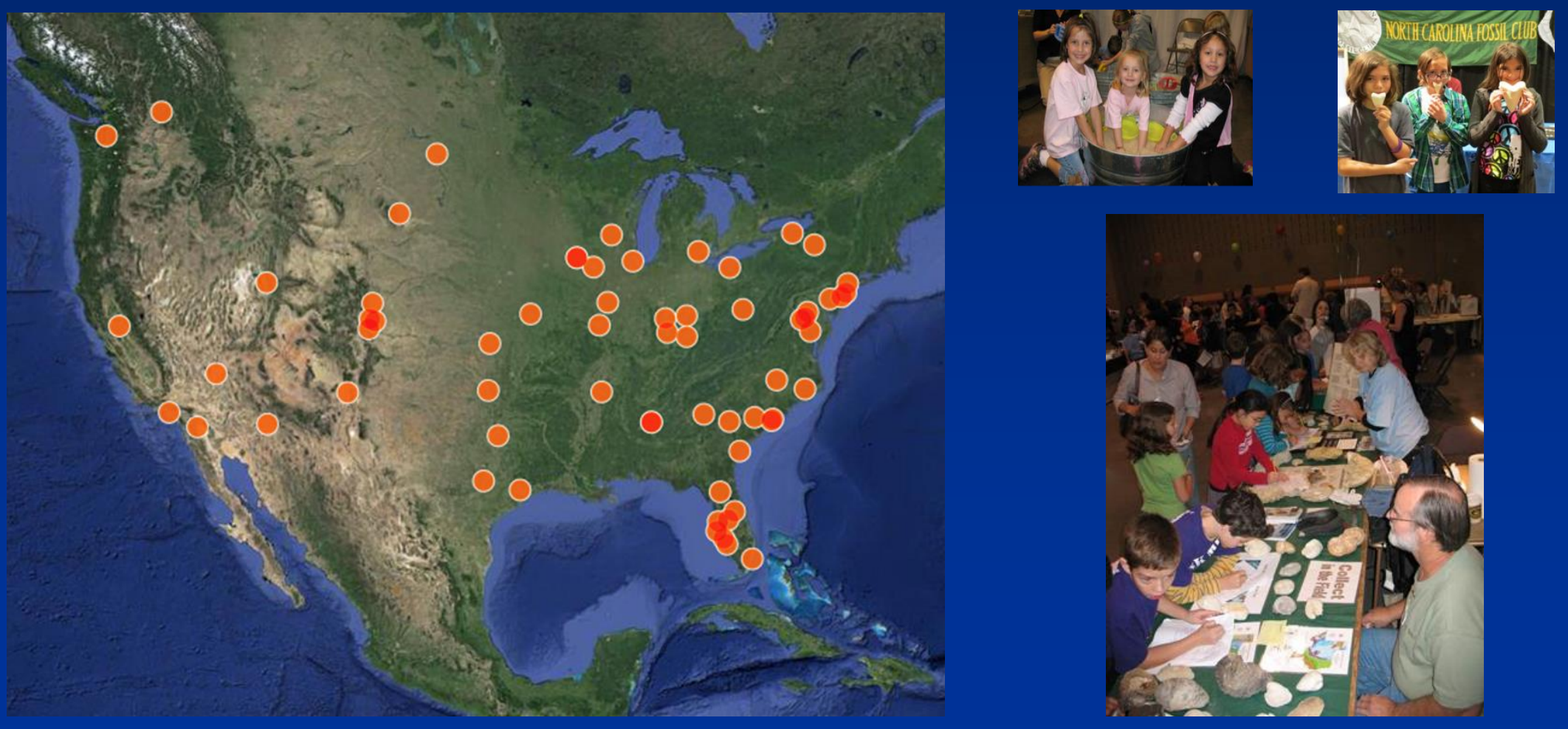


\section{What AA Clubs have to offer}

We are the Field Associates for the Professionals

- 12,000 potential allies in the field

- Most clubs collect primarily invertebrates

- $75 \%$ of scientifically relevant specimens found by amateurs

- We are out in the field a LOT, knowledgeable about our areas

- For every significant fossil you lose to a private collector you obtain hundreds or thousands more. The balance is clearly in favor of us being out there collecting.
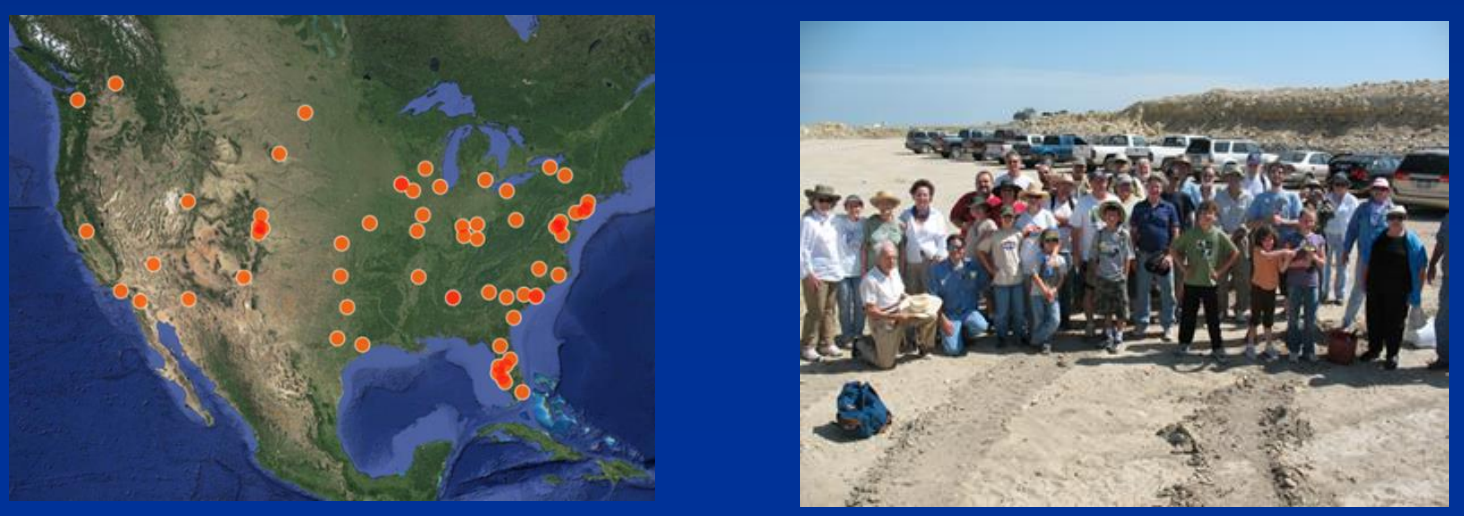

Can citizen scientists make a difference ?

Yes!

- $75 \%$ of all scientifically important specimens are found by amateurs (Rob Weems)

- $85 \%$ of all scientifically important elasmobranch specimens are found by amateurs (Brett Kent) 


\section{What AA Clubs have to offer}

We can help professionals document, curate, publish

- Donation of your time (guide and mentor us)

- Lack proper training in collecting techniques/prep/curation

- Lack access to research material

- Lack access to professional conventions

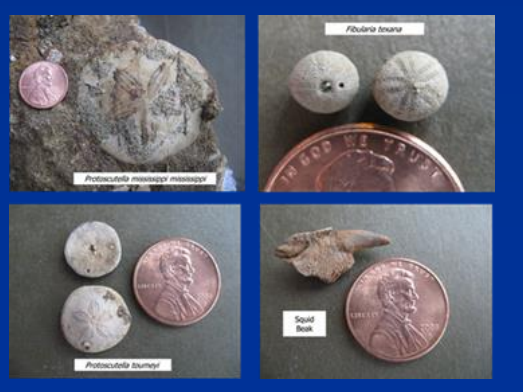

Fossil

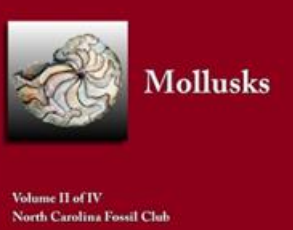

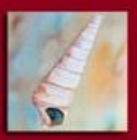

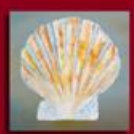

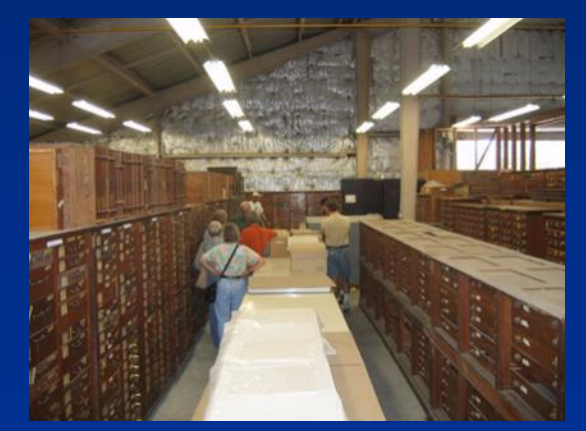

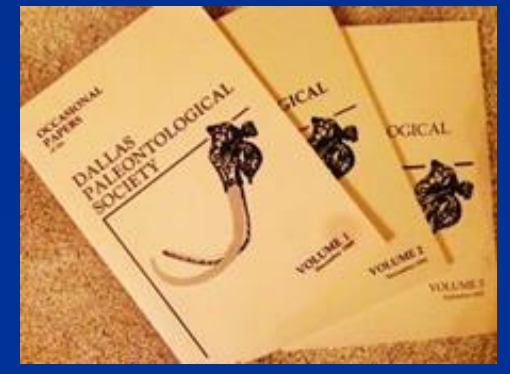




\section{Break Down the Barriers}

Break down the barriers of distrust between us

- FOSSIL Project a start - but we need a LOT more done

- Bias even here

- Raleigh Museum of Natural Science Paleopalooza cancelled

- Challenge to Professionals and to Amatuers

- Underutilized resource - we are on the same side

- Synergistic partnership between us has exponential benefits for all of Paleontology 


\section{The End}




\section{Acknowledgements}

FOSSIL Project

\section{Chuck Ferrara \\ Lee Cone \\ Jack Kallmeyer}

- PoSA members:

- Ed Elliott, Suzanne Galligher, Chris Garvie, Kevin Durney, Mike Smith, Erich Rose, Scott Kelley

- SoCAL members;

- Jennifer Morita, John Tabor

- NCFC members

- Richard Chandler, Joy Herrington, James Bain, George Powell, Jerry Case, Eric Sadorf, Mike Bruff, Emily Bruff, Don Clements, Jonathan Fain, Diane Willis

- Emails with all 15 clubs surveyed 